\title{
Diversity, innovation and entrepreneurship: where are we and where should we go in future studies?
}

\author{
Charlie Karlsson • Jonna Rickardsson • \\ Joakim Wincent
}

Accepted: 18 June 2019 /Published online: 24 October 2019

(C) The Author(s) 2019

\begin{abstract}
In this paper, we review and comment upon the development of the literature on diversity, innovation, and entrepreneurship. In an overview of previous studies and various strands of literatures, we outline and argue that to better understand the intricate dynamic relationships between diversity, innovation, entrepreneurship, and regional development there is a strong need to further develop "the economics of spatial diversity." We further argue that this development may benefit from combining various literatures based upon sound economic micro-foundations, to develop a more absolute understanding of diversity and fulfill the need of more clear mechanisms for future empirical testing. Obviously, this is important both from a research point of view and in order to provide policymakers with a powerful set of analytical tools. We call for more analytical work and more high-quality empirical studies. With a set of papers, we believe this special issue to provide a contribution in this direction.
\end{abstract}

C. Karlsson $(\bowtie)$

Jönköping International Business School, Blekinge Institute of Technology, Karlskrona, Sweden

e-mail: charlie.karlsson@ju.se

J. Rickardsson

Jönköping International Business School, Jönköping, Sweden

J. Wincent

Hanken School of Economics, Helsinki, Finland

J. Wincent

University of St. Gallen, St. Gallen, Switzerland
Keywords Economics of spatial diversity - Diversity . Innovation · Entrepreneurship · Regional development

JEL codes $\mathrm{R} 11 \cdot \mathrm{O} 12 \cdot \mathrm{O} 31 \cdot \mathrm{M} 13 \cdot \mathrm{M} 14 \cdot \mathrm{M} 21 \mathrm{~L} 26$

\section{Introduction}

Innovation and entrepreneurship are about finding new creative solutions to address demanding challenges at all societal levels through looking upon problems from new perspectives and using resources in new combinations in both established and new firms. These challenges exist at local and regional levels - urban as well as rural-and national and international levels (see for example Audretsch and Keilbach 2007, 2008). In many cases, the new ways of thinking, working, and solving problems call for new types of innovators, entrepreneurs, and intrapreneurs as well as proactive economic agents in the private, the public, and the non-for-profit sectors that support and facilitate change. Different complex challenges and problems call for a diversity of perspectives, ideas, and skills to ensure that a broader set of resources, capacities, and capabilities are used and that multiple economic actors interact to bring together many types of knowledge, skills, and competences.

Although contemporary research on diversity suggests that it exists on different levels, our understanding is rarely reviewed and discussed from such basis. Against this background, we examine previous literature and ideas and directions for future research on diversity at various levels, taking into consideration the different 
roles of diversity on knowledge generation and externalities, innovation, and entrepreneurship as well as the interdependence of these levels of diversity. In this paper, we also introduce the different contributors to this special issue. This special issue contains most of the key-note presentations at the 21st Uddevalla Symposium, Luleå, Sweden 2018, which had the purpose to bring together a group of international scholars to present and discuss new aspects of diversity, innovation, and entrepreneurship from regional, urban, national, and international perspectives. With a diverse set of papers, which all have been revised after having gone through a peer review process, it is our hope that this special issue implies a small contribution to "the economics of spatial diversity."

\section{Diversity, innovation, entrepreneurship, and regional development - an introduction}

Regions are more and more regarded to be critical drivers of economic development with urban regions as the main nodes in the global economy (Malecki 2007). The innovation and the entrepreneurship that they have a capacity to spawn are increasingly seen as the key factor underpinning their future growth trajectories (Fritsch and Mueller 2004). Urban regions have in the modern knowledge economy become incubators of new ideas and provide opportunities for the discovery of new valuable knowledge, which generates a foundation for innovation and entrepreneurship (Huggins and Williams 2011). Researchers have long studied the economic success of urban regions trying to understand what factors are driving their pre-eminent economic development. A growing body of research is today stressing the links between on the one hand regional diversity and on the other hand regional knowledge generation, innovation, and entrepreneurship. It is today a stylized fact that larger cities tend to be more diversified than smaller ones (Duranton and Puga 2000), and diversity in urban regions has often been seen as the unique asset of cities and what makes their wealth and drives their long-term economic development and growth (Jacobs 1969; Florida 2002). Diversity of regions and nations has many dimensions and include nationality, ethnicity, culture, religion, language, gender, education, experience, occupation, knowledge mix, industrial mix, and so on.
A large set of empirical studies supports the view that there are positive effects of diversity. ${ }^{1}$ Over the last two decades, the empirical evidence of "spatial diversity economies" in terms of creativity (Andersson et al. 2005), innovation (Ozgen et al. 2012), entrepreneurship (Rodríguez-Pose and Hardy 2015), and productivity (Trax et al. 2015) has multiplied. Population diversity has, for example, been found to have a positive influence on economic development in the short, medium, and long run, and while this relationship is attenuating after 30 years, it stays strong (Rodríguez-Pose and von Berlepsch 2018). Quigley (1998, 136) in a survey on urban diversity and growth writes:

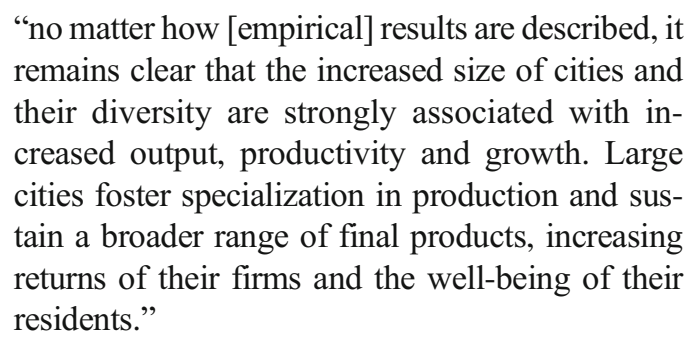

The interest in diversity is not a new phenomenon. Researchers has for several decades explored the effects of diversity, especially in urban regions. It has in regional and urban economics been demonstrated that there exists a fundamental relationship between market size and diversity. For example, in spatial models, building upon the general model of monopolistic competition developed by Dixit and Stiglitz (1977) drawing upon Chamberlain (1933), diversity in inputs generates increasing returns at the aggregate level (Fujita and Thisse 2002). Due to increasing returns of diversity in intermediaries, firms located in a region with a diverse set of input suppliers will have higher productivity than similar firms located in a region with a less diverse supply of inputs.

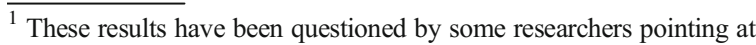
the difficulties in developing a workable definition of diversity as well as measuring it (Rosenthal and Strange 2004). The smaller the area of analysis, ceteris paribus, the greater the apparent levels of specialization, while the larger the area, the greater will be the apparent level of diversity. This endogeneity of the area size is a variation on the modifiable unit area problem (Openshaw and Taylor 1999), which needs to be controlled for. Malizia and Feser (1999) make an important remark in this respect: "Economic diversity is the presence of multiple specializations. This definitional point deserves emphasis because the diversity literature is confusing."
} 
Jacobs (1969) developed the theory of external economies which discusses the role of diversity on regional growth. Jacobs argues that cultural heterogeneity within a labor force expands the collective variety of skills, knowledge and ideas that are contained within it, becoming a vital and precious economic asset for a region's economic development. Furthermore, diverse regional populations provide a richer mix of skills, tastes, and ideas, which span across a wider range of cultures (Sobel et al. 2010) but also a richer mix of intra- and interregional networks, i.e. a larger network capital (Huggins and Thompson 2015). This facilitates interaction and flows of ideas, information, and knowledge within and across regions both vertically and horizontally (Contractor and Lorange 2002). Jacobs' understanding of the drivers of regional growth are in line with the explanations offered by modern models of endogenous economic growth, where the generation, transfer, and use of knowledge within and across regional economies increasingly are seen as the main drivers of regional economic growth (Antonelli et al. 2011).

One of Jacobs' insights is that urban development and growth stems in large part from the possibility that individuals can experiment with and combine different sources of knowledge and interact with individuals with different experiences and background. The differentiated education, experiences, and cultural background of people shape the idiosyncratic ways in which different people interpret, understand, and evaluate the world around them (Noteboom 2000). This implies that a higher diversity may benefit regional economies by expanding the regional knowledge base as well as increasing its absorptive capacity (Cohen and Levinthal 1990), improving its ability to identify, evaluate, assimilate, and exploit new knowledge (Hong and Page 2001).

The more diverse a region's population, the wider the range of accessible knowledge stemming from people's varying backgrounds and the more possibilities to combine existing knowledge (Qian 2013). ${ }^{2}$ Desrochers (2001) suggests that a diversified city, where diversity also includes cultural diversity (Nathan and Lee 2013), is likely to increase the probability of combining existing resources in different configurations by offering

\footnotetext{
${ }^{2}$ Several studies from both the USA and Europe provide empirical evidence of a positive effect of migrant diversity on average labor productivity (Sparber 2007; Huber et al. 2010). Südekum et al. (2009) found positive wage and employment effects for the size and mix of high-skilled migrants but not for lower-skilled migrant workers in German regions.
}

a greater number and variety of problems to be solved, as well as a much wider pool of expert knowledge and other resources to develop new solutions. Furthermore, communication between individuals that do not have a common knowledge base is facilitated by geographical proximity and its resulting increased face-to-face communication.

The above discussion displays a positive relationship between regional diversity and regional performance. However, the discussion on whether it is localization externalities or diversity externalities that brings most economic growth is still topical. ${ }^{3}$ More recently, there is also a growing literature arguing that too much diversity or too much specialization, in terms of skills, industry mix, etc. can aggravate regional growth. Frenken et al. (2007) introduce the concepts of related and unrelated variety and argue that geographical proximity is not enough for knowledge to spill over across individuals and firms, but some sort of cognitive proximity must also be present. Frenken et al. (2007) defines related variety as within-industry diversity and unrelated variety as between-industry diversity. Empirical studies confirm that related variety, associated with Jacobs-type diversity externalities across related industries have significant effects on regional development (Frenken et al. 2007; Boschma and Iammarino 2009; Neffke et al. 2011). Empirical results on unrelated variety are more mixed.

There is also a growing literature on the effects of various forms of diversity on firm performance. Lazear (1999) developed a model concerning the role of workforce diversity for firm-level outcomes. The model envisions a positive effect of educational/skill diversity on firm performance as long as the information sets of the employees are not overlapping but relevant to one another. Educational diversity is here a proxy of skill complementarity and thus a potential for intrafirm knowledge spillovers, which is likely to have a positive influence on a firm's innovation output. In a similar manner, Boschma et al. (2009) apply the concepts of related and unrelated variety on a firm level. They argue that related - but not unrelated - variety increases productivity, as diversity within a firm increase knowledge, but only if workers are cognitive close enough for

\footnotetext{
${ }^{3}$ The famous controversy, known as MARS versus Jacobs, i.e., the role of localization externalities, based on agglomeration and specialization (Marshall-Arrow-Romer) versus the role of diversity externalities (Jacobs).
} 
learning to happen. Berliant and Fujita (2011) suggest a model where the composition of a research labor force in terms of knowledge heterogeneity positively affects the generation of new knowledge as it accelerates the generation of novel ideas through production complementarities at the individual level. One can also assume that employees of different cultural backgrounds as well as of different age may provide diverse perspectives, valuable novel ideas, and new problem-solving abilities and thus contribute to optimal creative solutions and thereby stimulating innovation (Lazear 1998; Hong and Page 2004). ${ }^{4}$ These dynamics appear particularly important in knowledge-intensive work environments such as science labs, high-tech and creative industries, or business services (Fujita and Weber 2003).

The promotion of diversity is often seen as a possibility to improve learning and knowledge management capabilities, which would enhance firm productivity (Parrotta et al. 2012). As an example, one can expect diverse leadership teams to be better at generating new ideas or solving problems, specifically in knowledgeintensive environments (Page 2007). ${ }^{5}$

In addition to diversity in terms of nationality, culture, education, experience, age, industrial mix, and so on, respectively, the entrepreneurial ecosystem approach considers the interdependence of these elements and how they work together in a social and economic environment in creating a rich entrepreneurial milieu. Recently, the literature on entrepreneurial ecosystems has grown large. This strand of literature uses a system approach to understand and examine the role of the regional context on entrepreneurship. An entrepreneurial ecosystem consists of a diverse set of actors and factors that enable or hinder entrepreneurial activities within a, e.g., region, city, or country (Malecki 2018). ${ }^{6}$ This diverse set of components, external to the individual entrepreneur, is essential for the choice of a person to become an entrepreneur and for the likelihood of an entrepreneurial success (Nijkamp 2003; Van de Ven 1993). Examples of elements are culture, education and universities, and institutions (Brown and Mason

\footnotetext{
${ }^{4}$ Parrotta et al. (2014) found evidence for the hypotheses that ethnic diversity of the workforce facilitates a firm's patenting activity.

${ }^{5}$ However, a high degree of heterogeneity among employees may also induce misunderstandings, conflicts, and un-cooperative behaviors within workplaces and thus hinder creativity and innovation (BassettJones 2005).

${ }^{6}$ Empirical studies have affirmed the relationship between strong entrepreneurial ecosystems and entrepreneurship (e.g., Fritsch 2013; Stam and van de Ven 2019).
}

2017; Pugh et al. 2019; Stam 2015; Stam and van de Ven 2019). A system perspective is beneficial when many elements are interrelated and operate simultaneously. One can connect the literature on regional diversity and the literature on entrepreneurial ecosystems and a combination of these alignments can potentially help us to deeper understand the role of the regional context on local entrepreneurship. While diversity in, for instance, culture, can boost entrepreneurship, it is also likely that cultural diversity attracts a diverse set of individuals (e.g., in terms of age, education, and nationality), hence promoting more regional population diversity, and vice versa. Ecosystem elements are interdependent and so are the level of diversity within these elements, why diversity in some elements can boost diversity in others, all inducing local knowledge and entrepreneurship.

\section{Diversity and knowledge generation in urban regions}

Urban regions function as birth places for new knowledge, new technologies, and innovations in the form of new products and new production methods. This implies that they contain, attract, and enable success for economic agents with innovative skills and potential, due to the specific economies of scale, which tend to develop in such regions (Marshall 1920). There are two major groups of external economies: pecuniary externalities and knowledge externalities (Krugman 1991; Ellison and Glaeser 1997). Pecuniary externalities emanate from natural regional advantages such as natural and/or man-made resource endowments, advantageous location, and/or comparatively low labor costs (Ellison and Glaeser 1999). Knowledge externalities, on the other hand, need not be related to natural regional advantages but to a regional economic milieu that attracts a diverse set of highly skilled people, whose varied knowledge, experiences and competencies, and knowledge exchange contribute to increase the regional knowledge stock.

Private economic agents engage in the production of potentially valuable new knowledge as a means to generate innovations based upon the assumption that the newly generated knowledge is not a pure public good but at least partially excludable by claiming intellectual property rights to the new knowledge (Audretsch 2000). Even if we assume that this knowledge is non-rival, that 
does not imply that it is freely and immediately accessible by everyone in the region. Specifically, new knowledge is not only highly specialized but also "sticky" (von Hippel 1994), i.e., highly contextual and uncertain. This implies that the individuals who shall evaluate it and possibly apply it must have the relevant training and experience but also opportunities for frequent face-to-face interaction to fully interpret and understand it, in what often is a time-consuming process.

Knowledge externalities, due to knowledge spillovers, make increasing returns to scale possible. However, the effects of accumulated knowledge are not uniform across geographical space. "The new economic geography" contends that new knowledge gets accumulated in the locations where it has been produced and explains the importance of spatial proximity for local knowledge spillovers. These localized spillovers increase $\mathrm{R}$ and $\mathrm{D}$ productivity among economic agents performing $\mathrm{R}$ and $\mathrm{D}$ and increase general productivity of economic agents whether they are investing in R and $\mathrm{D}$ or not. Knowledge spillovers consists of (i) pure knowledge spillovers that are uncharged, unintended, and not mediated by any market mechanism; (ii) embodied knowledge spillovers associated with the transaction of a non-standardized product; and (iii) traded knowledge spillovers involving at least a partial payment for the knowledge (Andersson and Ejermo 2005). The mechanisms behind knowledge spillovers have not been penetrated in detail in the literature (Storper and Venables 2004) but include (i) formal and informal interaction between economic agents with formal and informal contracts, respectively, (ii) active knowledge search by economic agents, and (iii) mobility of economic agents, not least personnel (Karlsson and Gråsjö 2019). In this connection, one can assume that more codified forms of knowledge are less distance sensitive than more tacit knowledge and thus that codified knowledge spills over faster spatially than tacit knowledge (Bathelt et al. 2004), which implies that tacit knowledge tends to determine the geography of innovation (Asheim and Gertler 2005).

Obviously, urban regions and specifically large urban regions have great advantages in terms of knowledge evaluation and adoption since they offer a large and diverse supply of highly skilled people and a welldeveloped intraregional transport infrastructure together with a large variety of different meeting places suitable for both planned and unplanned face-to-face interaction. Thus, urban regions offer comparative advantages in the diffusion and generation of new knowledge (Henderson 2005) and the costs for innovation tend to be lower in such regions (Feldman 1994), since knowledge has a strong propensity over time to spill over (Arrow 1962) from the knowledge-creating firm to other third-party firms, which can access that knowledge at relatively low cost (Acs et al. 2013). As a result, the formative, innovative stages of product development are more likely to be located in urban regions with diverse economies and corresponding spillovers, both which are conducive to the creation of new products (Duranton and Puga 2001).

Empirical evidence indicates that knowledge is sticky and spillovers are dissipating with distance. Jaffe et al. (1993), for example, find newly developed knowledge, codified as patents, to be sticky, and to stimulate the development of new knowledge within the same region, specifically. This further implies that there is a distance decay in the diffusion of knowledge, since much critical knowledge tends to be tacit, i.e., embodied in people and thus at least in the short-run stuck in the region where it was developed (Audretsch and Feldman 1996; Kekezi and Klaesson 2019).

Similarly, Capone et al. (2019) examine the role of knowledge networks on the inventive performance of cities. They find that the structure of knowledge networks, based on interfirm co-patenting collaborations, induce cities' inventive capacity. The results also indicate that a greater diversity/variety of a city's industrial structure boosts the inventive performance of a city.

The relationship between knowledge and economic performance at the regional level is also influenced by the mediating role of institutions, and regions with strong informal institutions are generally more successful (Kemeny 2012). Also, trade policies can affect knowledge, and hence knowledge externalities. Foreign multinational enterprises can generate local knowledge externalities that can benefit local entrepreneurs, but they can also harm local entrepreneurs and hinder their new ventures to thrive. Bhawe et al. (2019) show that two protectionist policies, import tariffs and subsidies, affect the diversity of local entrepreneurship differently depending on the city's ability to absorb new knowledge.

\section{Diversity and innovation in urban regions}

Innovations, which are yet unstandardized goods and services, play a fundamental role for the renewal and 
growth of regional and national economies. Innovations can be placed at a continuum ranging from incremental innovations via major (or adaptive) innovations to radical innovations (Andersson and Karlsson 2006). In particular, more radical innovations tend to a high extent be brought into the market through the entry of new firms (Aghion et al. 2009). This implies that the initiating factor behind innovation and thus entry often originates outside the set of incumbent firms but from firms and/or basic research laboratories in technology-related industries (Winter 1984). As the knowledge generated in private as well as public, $\mathrm{R}$ and $\mathrm{D}$ laboratories is likely to spill out, urban regions offer an atmosphere consisting of a diversity of potential intellectual spillovers waiting to be identified, evaluated, and absorbed by potential and active entrepreneurs. This is consistent with the idea of inter-industry spillovers resulting from the diversity in urban regions advanced by Jacobs (1969). If innovation is understood as the combination of previously unrelated knowledge bits (Schumpeter 1934), it seems obvious that diversified cities will be more likely to generate innovations than specialized ones. $^{7,8}$

Since innovation is a complex process often requiring knowledge and competence from other economic agents, links to other economic agents is a critical aspect of the innovation process (Bergenholtz and Waldstrøm 2011). These links, which facilitate the flow of ideas, R\&D, knowledge, technology, skills, expertise, and competence, include both supplier-customer links and links to economic agents such as competitors, consultancy firms, R\&D firms, and research universities (Andersson and Karlsson 2007). Innovating economic agents create innovation cooperation networks which reduce information asymmetries between knowledge suppliers and knowledge buyers (Malecki 2010). Even if innovation cooperation networks tend to be localized, they also need global knowledge links to avoid the risk of becoming rigid and outdated (Ter Wal and Boschma 2011). Since regional, national, and international economies change over time in evolutionary processes new sources of ideas, knowledge, technology, skills, and competence emerge more or less continuously and innovative firms more or less constantly need to renew

\footnotetext{
${ }^{7}$ A number of empirical studies from both the US and Europe provide evidence for a link between urban diversity and innovative activity (Peri 2007; Ozgen et al. 2012).

${ }^{8}$ This implies that diversity policies and practices might have increased creativity and innovation as a key benefit (EC 2005).
}

their innovation cooperation networks to avoid lock-in in obsolete knowledge and technologies (Labianca and Brass 2006).

The introduction of new products can be expected to be more frequent in large urban regions where it costs less to develop innovation cooperation networks and access to networks with the right knowledge and competence profiles is greater (Grant and Baden-Fuller 2004). Firms located in large urban regions may often be embedded in intra- and inter-regional knowledge networks (Krätke 2010) with access to regional knowledge sources through local knowledge links (Mueller 2006) as well as non-local knowledge "pipelines" (Bathelt et al. 2004). Of course, innovative firms and in particular those that belong to a multinational firm will also often source knowledge from other regions (Davenport 2005). In particular, for firms in smaller regions inter-regional sourcing functions as a substitute when local knowledge is not available (Drejer and Vinding 2007).

Despite the options to source knowledge inter-regionally, firms embedded in regional knowledge networks have a competitive advantage ${ }^{9}$ due to larger likelihood of finding (i) a diverse set of knowledge producing organizations, (ii) a large and diverse supply of highly skilled people, ${ }^{10}$ (iii) a diverse set of qualified cooperation partners, and (iv) a diverse set of appropriate input suppliers. A diverse set of knowledge-producing organizations in a region implies access to a varied output of new knowledge, which can be used as an input in innovation processes. A diverse supply of highly skilled people and a diverse set of qualified regional innovation cooperation partners can be expected to have a positive impact on firm innovation performance because a richer supply of complementary knowledge and localized collaborative knowledge development may generate synergetic effects (Lavie 2009), ${ }^{11}$ which is an example of a localized knowledge externality. The co-location of entrepreneurs and innovating firms and their input suppliers

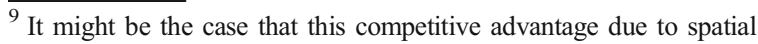
proximity to local knowledge sources is reduced over time (Fitjar and Rodríguez-Pose 2011). However, the advantages of spatial proximity to a skilled labor force, qualified suppliers, and demanding customers with a willingness to pay for new innovative products remain.

${ }^{10}$ Several studies provide evidence of a positive relationship between the presence of a diverse set of high-skilled workers and regional innovation (Hunt and Gauthier-Loiselle 2010; Kerr and Lincoln 2010).

${ }^{11}$ van Beers and Zand (2014) show that functional and geographic diversity of R\&D partners affects radical and incremental innovation performance of product innovating firms.
} 
can be described as a localized input-demand externality (cf. Marshall 1920). Normally, larger urban regions offer stronger input-demand externalities, which explain why the probability that industries supplying novel products will locate in such regions is high (Johansson and Andersson 1998). In those cases, where firms that supply distance-sensitive products benefit from a location where there are sufficient customers with a preference for new innovative products and a high enough willingness to pay for these products, there exists a localized output-demand externality (cf. Krugman 1990).

Product cycle models assume that output-demand externalities affect where the supply of novel products is successfully located (Hirsch 1967). During the product innovation phase of the product cycle, each supplier is assumed to communicate intensively through links with its customers and this is a distance-sensitive activity, since this communication to a high extent needs to be face-to-face. In addition, it is assumed that for a novel product only a small fraction of all potential customers is willing to test and experiment with the new product (Vernon 1966). As a consequence, this small fraction will represent a sufficiently large demand only in large urban regions. Urban regions and specifically large urban regions offer a diverse supply of knowledge and a large enough and diverse internal market potential with advanced customers demanding new advanced solutions, to make the launch of innovations profitable. Urban regions further benefit from low internal geographical transaction costs, which are critical for reducing the interaction costs for the entrepreneurs. Thus, innovative activities show a strong tendency to cluster particularly in large urban regions (Karlsson 2016) and knowledge-intensive and high-tech industries tend to locate in spatial patterns with a preference for larger urban regions with a rich and diverse set of higher education, research, and cultural and other amenities.

\section{Diversity and entrepreneurship in urban regions}

Entrepreneurs in urban regions are likely to have lived in the region all their life or at least to have lived and worked there for many years (Greene et al. 2008). This implies that these entrepreneurs have had time to create dense business, professional and social networks based upon past experience and frequent interactions with other people in the region that provide access to a diverse set of information and knowledge. These networks facilitate the start-up process including resource acquisition (Stuart and Sorensen 2005). Hence, entrepreneurship should be looked upon as a regional phenomenon (Stam 2007) stimulated by the entrepreneurial opportunities, which emerge from diversified regional economic milieus offering a variety of knowledge externalities which stimulate various kinds of innovation-driven entrepreneurship. According to this perspective, entrepreneurship is viewed as an endogenous response to the local knowledge environment, placing the characteristics of the region in focus (Audretsch and Keilbach 2007).

New knowledge developed by other economic agents is identified as a critical source of new entrepreneurial opportunities, since most entrepreneurs have not developed any new knowledge themselves (Doran et al. 2012). Actually, it is assumed that entrepreneurs play an important role in commercializing new knowledge developed in large incumbent firms and research institutes (Qian and Acs 2013). Because of partial excludability, new knowledge cannot be monopolized by those economic agents who generated it and may thus "spillover" to other economic agents. However, accessing knowledge developed by other economic agents requires spatial proximity, which implies that entrepreneurship tend to cluster within close proximity to the knowledgeproducing economic agents (Acs et al. 2013). However, it is not clear what the links between the knowledgeproducing economic agents and the entrepreneurs look like (Hayter 2013).

Entrepreneurs are those economic agents that translate accessible knowledge in the region into economically useful knowledge or that penetrate the "knowledge filter" (Acs and Plummer 2005) but their ability to do so is dependent upon their existing network as well as their ability to create new links to other economic agents with critical knowledge and skills (Anderson et al. 2010). The translation approach suggests that entrepreneurship is the conduit for $R \& D$ results to find their ways into profitable economic applications. Without entrepreneurs, the regional knowledge stock would not influence regional economic performance (Audretsch and Keilbach 2008). The penetration approach, known as "the knowledge spillover theory of entrepreneurship," postulates that the greater the accumulated regional knowledge stock, the greater the volume of new knowledge generated, and the more knowledge generated the greater the volume of new knowledge that remains unused among the economic agents generating the 
new knowledge and the greater the regional supply of entrepreneurial opportunities (Acs et al. 2009). ${ }^{12}$ Due to the intrinsic uncertainties associated with new knowledge (Arrow 1962) leading to asymmetric evaluation of their market potential only a portion of the opportunities generated by the new knowledge will be pursued by the organization investing in $\mathrm{R} \& \mathrm{D}$, which creates a stock of unrealized opportunities that can be identified, evaluated, and possibly commercialized by entrepreneurs.

The more diverse the new knowledge generated in a region, the higher the probability for a high volume of entrepreneurship. At the same time, we have that diverse creative economic agents perceive and value potential market opportunities differently, which makes the discovery and exploitation of potential market opportunities more likely to occur in more diverse regions (Qian et al. 2012). ${ }^{13}$ Generally, one could assume that diverse populations and work forces not only create a potential for knowledge spillovers but also a larger potential to exploit the larger pool of talents, perspectives, and social connections, which make the people in them more responsive to the recognition and exploitation of gaps and opportunities in the regional economy with a larger volume of entrepreneurship as a possible result (Eraydin et al. 2010). This increases the diversity in the regional supply of goods and services as well as drives a selection process, where some obsolete goods and services and firms are forced out of the market (Sautet and Kirzner 2006). We could here talk about direct and indirect supply side effects, which collectively and interactively influence a region's accessible knowledge stock, the knowledge spillovers which will take place, and the idiosyncratic ways in which knowledge with commercial value is identified, evaluated, and exploited through entrepreneurship. Diversity has also been found to strengthen regional resilience to economic shocks. The larger the size and the diversity of the local knowledge stock the better the ability of entrepreneurs to facilitate regional adaption to economic crises (Bishop 2019).

Diversity also has important demand-side impacts on entrepreneurship. A diverse population will generate a demand for diverse goods and services from different population groups and thus generate diversified market

\footnotetext{
12 Tsvetkova (2015) found empirical support for "the translation hypothesis" but not for "the penetration hypothesis."

${ }^{13}$ The number of studies that examine the value of cultural diversity for entrepreneurship seems to be rather limited (Audretsch et al. 2010; Cheng and Li 2012; Rodriguez-Pose and Hardy 2015).
}

opportunities for potential entrepreneurs to exploit (Porter 1995).

\section{Conclusions}

The discussion above clearly illustrates that to more fully understand the intricate dynamic relationships between diversity, innovation, entrepreneurship, and regional development there is a strong need to further develop "the economics of spatial diversity" based upon sound economic micro-foundations, the identification of a number of clear mechanisms amendable to rigorous empirical testing, including the identification of causal effects. This is necessary both from a scientific point and from the need to provide policymakers with a richer and more powerful set of analytical tools, since "the economics of spatial diversity" is still a work in progress in need of both more analytical work and more highquality empirical studies. It is our hope that this special issue implies a small contribution to "the economics of spatial diversity."

\section{The contributions in this special issue}

All papers in this special issue are a selection of those presented at the 21st Uddevalla Symposium that was held in Luleå, Sweden, June 14-16, 2018, hosted by Luleå University of technology. The theme of the symposium was "Diversity, Innovation, EntrepreneurshipRegional, Urban, National and International Perspectives." The research questions highlighted in this special issue are of high policy relevance and relate to many current and pertinent regional, national, and international policy issues. Among the contributions is the examination of knowledge spillovers, and its induction on entrepreneurship and innovation, and how knowledge can be obtained through social networks and obstructed by protectionist policies. Moreover, while human capital spillovers can induce the emergence of innovative startups, they are distance sensitive and the effect attenuates hastily with geographical distance. The diffusion of knowledge also depends on the regional and/or national entrepreneurial ecosystem, consisting of all factors and actors that interdependently enable and hinder entrepreneurship. Institutions and policies play an important role in these ecosystems. The papers in this special issue show the importance of institutions and policies on, 
among other things, knowledge spillovers and innovation, female entrepreneurship, the well-being of entrepreneurs, and the decision-making process of governmental venture capitalists. Trade policies, for example, are found to affect knowledge externalities and regional entrepreneurship; family policies are found to affect the level of female entrepreneurship; and innovation/ business support programs are found to affect regional learning and entrepreneurship. Below is a more comprehensive summary of the papers and their contributions.

Based on theories on social networks and knowledge spillovers, Capone et al. (2019) explore the role of knowledge networks and their structure on the inventive capacity of cities. While the literature on knowledge networks and inventive performance is increasing, few studies have analyzed the relationship between the structure of local knowledge networks, diversity, and cities' inventive capacity. By using data from the REGPAT database on all patents issued in Italy between 2004 and 2016, the authors develop knowledge networks for 103 Italian provinces. In total, 68,000 patents and 17,000 firms are included in the networks which are based on interfirm co-patenting collaborations. The structure of these knowledge networks is then analyzed. Capone et al.'s (2019) contributions to the literature are twofold. First, they find that the structure of knowledge networks induces cities' inventive capacity. If actors are more connected in sub-graphs and if knowledge flows in higher hierarchical networks, then cities' innovative performance increases. Secondly, they find that greater diversity of a city's industrial structure boosts the inventive performance of a city. The study highlights the importance of the characteristics of cities' knowledge networks and the dynamics of how knowledge spreads locally.

Bhawe et al. (2019) examine the effect of protectionist policies, aimed at restricting foreign multinational enterprises (MNEs), on local entrepreneurship and diversity among new firms. While previous research suggests that these knowledge spillovers can benefit local entrepreneurship, the success of many MNEs in capturing significant portions of local markets have led to debates on whether restricting MNEs will protect local entrepreneurs and allow them to thrive. Bhawe et al. (2019) hypothesize that the impact foreign multinational enterprises have on local entrepreneurship, through knowledge spillovers, depends on an economy's ability to absorb these knowledge externalities. The authors model the dynamic interplay between
MNEs and diversity of local entrepreneurs, using an agent-based simulation. They examine how two protectionist policies, tariffs on imports and subsidies for local businesses, influence this dynamic. As hypothesized, the results differ depending on the economy's absorptive capacity. Local economies with low absorptive capacity would gain more from using protectionist policies in order to promote local entrepreneurship. Economies with a higher absorptive capacity, however, risk to be locked into replicative entrepreneurship with the imposition of tariffs. In these regions, tariffs can reduce the incentives to innovate and decrease diversity. Subsidies, on the other hand, when given to local entrepreneurs in high absorptive economies, can generate greater diversity in newly created firms. In order to prevent introducing harmful policies, the authors stress the importance of taking into account the economy's absorptive capacity when deciding what policy to implement.

Stam and van de Ven (2019) seek to critically review the literature on entrepreneurial ecosystems as well as introducing a conceptual framework for measuring such ecosystems. An entrepreneurial ecosystem consists of various actors and factors that enable or hinder entrepreneurial activities within a, e.g., region, city, or country. The growing literature on entrepreneurial ecosystems uses a system approach to understand and examine the role of the regional context on entrepreneurship. The entrepreneurial ecosystem concept, however, is still loosely defined. Stam and van de Ven (2019) propose an integrated model that connects the components of entrepreneurial ecosystems with entrepreneurial output and welfare outcomes. The authors introduce a methodology for measuring the quality of entrepreneurial ecosystems, by creating an index out of 10 ecosystem elements, and use it to examine the entrepreneurial ecosystem in 12 regions of the Netherlands. The results suggest that the quality of entrepreneurial ecosystems is strongly related to the entrepreneurial output. Strong ties between the ecosystem components also show their mutual dependence and the subsequent need for a systems perspective.

Also, the study by Pugh et al. (2019) deals with the concept of entrepreneurial ecosystems. They believe the concept suffers from not adequately considering how learning occurs within regional ecosystems. In order to fill this gap and extend the literature, Pugh et al. (2019) conduct a case study on the North West of England and analyze research conducted in this area during a time span of over 20 years. In particular, the paper looks at 
three innovation/business support programs implemented in this area, run partly by the Lancaster University and with the goal to increase learning, by analyzing their design, their aim, who they involved, and their outcomes. Based on the accumulated research, the authors argue that learning is a crucial element and should be more holistically incorporated in the concept of entrepreneurial ecosystem. They promote the role of universities as catalysts for creating and sustaining highgrowth entrepreneurial activities, both at the individual entrepreneurial level and the wider regional level. Universities do not only provide high-skilled labor but also can increase learning by engaging with local businesses and by using their pedagogical skills. Hence, universities promote learning and reflection and build up business networks and should be considered both within the theoretical frameworks and in policy concerning support and encouragement of entrepreneurship within regions.

Audretsch (2019) reflects upon the Silicon Valley Model of Entrepreneurship, how and why it emerged, and how it helped ignite the entrepreneurial driven economies of the world. While the Silicon Valley Model of Entrepreneurship is compelling, this paper aims to illustrate the limitations of the model. Audretsch (2019) does not suggest that the Silicon Valley Model is ineffective, rather he emphasizes the profound importance of context. Audretsch concludes that the model seems to have been proficient in providing a way to penetrate the knowledge filter which inhibits investments in ideas and their transformation to innovative activity and subsequently to economic growth. Many regions, however, are not characterized by an inability to take advantage of investments in ideas and knowledge, rather they suffer from a shortage of such investments as well as a lack of human capital in the first place. Hence, the type of entrepreneurship that works in the context of Silicon Valley may work in other regions - but certainly not in all.

Johansson et al. (2019) give us a "behind-the-scenes" assessment of government venture capitalists' behavior and on how institutional logics work at the micro-level. The authors use longitudinal observation of closed-door meetings, interviews, documentation, and secondary data to examine how governmental venture capitalists take financing decisions. In an effort to understand the decision-making process of governmental venture capitalists, they examine how the decisions are influenced by cognitive, regulative, and normative spheres and show how these often pull in opposing directions, making it difficult to arrive at objective decisions. The authors find that the financiers often cite regulations to claim validity for their decisions, wanting to convey their decisions being based on rational decision criteria. Yet, this study reveals that the cognitive logic dominated the decision-making process, and this was the case whether normative and regulative logics were present or not. Thereby, this study emphasizes the need for strong institutionalized assessment routines to reduce uncertainty and increase the quality of the decisionmaking process.

Fritsch et al. (2019) study the relationship between individual well-being (in terms of job and life satisfaction) and formal institutions, such as entrepreneurshipfacilitating entry conditions and labor market regulations. The paper examines this relationship for the year 2013 using survey data on individuals in 32 countries, and by including the Doing of Business index provided by the World Bank. The authors distinguish between self-employed and paid employed individuals in order to identify whether the relationship between well-being and the country's institutional framework varies between these two groups. They find that the well-being of both self-employed and paid employees is positively related to the Doing of Business index. By including an interaction effect, self-employed $\times$ Doing of Business index, however, they conclude that the relationship is stronger for self-employed individuals.

Naldi et al. (2019) examine which factors are key drivers of entrepreneurship among mothers of young children. They use Swedish microdata on all businesses started by mothers in Sweden between the years 2000 and 2014. The study confirms that unemployment and foreign background, which perhaps imply lacking language skills and social networks, are important drivers of entrepreneurship among women. However, and contrary to the mainstream view, the study finds that entrepreneurship among women in Sweden is highly related to the amount of paternity leave taken by the partners. This finding suggests that formal institutions, such as family policies encouraging more equally divided parental leave among parents, may alter informal institutions, like gendered expectations of roles and responsibilities, inspiring the fathers to take out more paternity leave and assume the role of the main child care provider and the mothers to make other career choices.

In her paper "Working for an entrepreneur: Heaven or Hell?” Nyström (2019) provides a literature review 
and insights about the employees working for entrepreneurs. More specifically, the author covers three perspectives; who are the individuals who work at entrepreneurial ventures, what are the working conditions for individuals working for entrepreneurs, and how do their career paths look after working for entrepreneurs? The reviewed research shows that new firms tend to hire workers who hold weaker positions at the labor market, which suggests that the decision to work for an entrepreneur can be driven by necessity, the lack of other options. The paper also identifies several areas that need further research. It is, for instance, shown that employees at new firms are more likely to, later on, become entrepreneurs themselves. It is, however, uncertain whether their experience from working for an entrepreneur affects their future performance as entrepreneurs.

Each paper in this special issue serves to shed light on the success of entrepreneurial ventures by investigating the importance of location, networking, knowledge spillovers, and institutions, among other things. The special issue does not give a comprehensive view of the entire field but rather points to certain areas of importance such as the importance of context, knowledge externalities, institutions and entrepreneurial ecosystems for inventive performance. Each paper included also seeks to further develop the body of knowledge by suggesting further areas of research.

Funding Information Open access funding provided by Jönköping University.

Open Access This article is distributed under the terms of the Creative Commons Attribution 4.0 International License (http:// creativecommons.org/licenses/by/4.0/), which permits unrestricted use, distribution, and reproduction in any medium, provided you give appropriate credit to the original author(s) and the source, provide a link to the Creative Commons license, and indicate if changes were made.

\section{References}

Acs, Z. J., \& Plummer, L. A. (2005). Penetrating the "knowledge filter"'in regional economies. The Annals of Regional Science, 39(3), 439-456.

Acs, Z. J., Braunerhjelm, P., Audretsch, D. B., \& Carlsson, B. (2009). The knowledge spillover theory of entrepreneurship. Small Business Economics, 32(1), 15-30.

Acs, Z. J., Audretsch, D. B., \& Lehmann, E. E. (2013). The knowledge spillover theory of entrepreneurship. Small Business Economics, 41(4), 757-774.
Aghion, P., Blundell, R., Griffith, R., Howitt, P., \& Prantl, S. (2009). The effects of entry on incumbent innovation and productivity. The Review of Economics and Statistics, 91(1), 20-32.

Anderson, A. R., Dodd, S. D., \& Jack, S. (2010). Network practices and entrepreneurial growth. Scandinavian Journal of Management, 26(2), 121-133.

Andersson, M., \& Ejermo, O. (2005). How does accessibility to knowledge sources affect the innovativeness of corporations? - evidence from Sweden. The Annals of Regional Science, 39(4), 741-765.

Andersson, M., \& Karlsson, C. (2006). Regional innovation systems in small and medium-sized regions. In The emerging digital economy (pp. 55-81). Berlin, Heidelberg: Springer.

Andersson, M., \& Karlsson, C. (2007). Knowledge in regional economic growth - the role of knowledge accessibility. Industry and Innovation, 14(2), 129-149.

Andersson, R., Quigley, J. M., \& Wilhelmsson, M. (2005). Agglomeration and the spatial distribution of creativity. Papers in Regional Science, 84(3), 445-464.

Antonelli, C., Patrucco, P. P., \& Quatraro, F. (2011). Productivity growth and pecuniary knowledge externalities: an empirical analysis of agglomeration economies in European regions. Economic Geography, 87(1), 23-50.

Arrow, K. (1962). Economic welfare and the allocation of resources for invention. The rate and direction of inventive activity: economic and social factors. N. Bureau.

Asheim, B. T., \& Gertler, M. S. (2005). Regional innovation systems and the geographical foundations of innovation. The Oxford handbook of innovation (pp. 291-317).

Audretsch, D. B. (2000). Knowledge, globalization, and regions: an economist's perspective. In J. H. Dunning (Ed.), Regions, globalization, and the knowledge-based economy (pp. 6381). Oxford: Oxford University Press.

Audretsch, D. B. (2019). Have we oversold the Silicon Valley model of entrepreneurship? Small Business Economics: Special issue on Diversity, Innovation, Entrepreneurship Regional, Urban, National and International Perspectives, forthcoming.

Audretsch, D. B., \& Feldman, M. P. (1996). Innovative clusters and the industry life cycle. Review of Industrial Organization, 11(2), 253-273.

Audretsch, D. B., \& Keilbach, M. (2007). The theory of knowledge spillover entrepreneurship. Journal of Management Studies, 44(7), 1242-1254.

Audretsch, D. B., \& Keilbach, M. (2008). Resolving the knowledge paradox: knowledge-spillover entrepreneurship and economic growth. Research Policy, 37(10), 1697-1705.

Audretsch, D., Dohse, D., \& Niebuhr, A. (2010). Cultural diversity and entrepreneurship: a regional analysis for Germany. The Annals of Regional Science, 45(1), 55-85.

Bassett-Jones, N. (2005). The paradox of diversity management, creativity and innovation. Creativity and Innovation Management, 14(2), 169-175.

Bathelt, H., Malmberg, A., \& Maskell, P. (2004). Clusters and knowledge: local buzz, global pipelines and the process of knowledge creation. Progress in Human Geography, 28(1), 31-56.

Bergenholtz, C., \& Waldstrøm, C. (2011). Inter-organizational network studies - a literature review. Industry and Innovation, 18(6), 539-562. 
Berliant, M., \& Fujita, M. (2011). The dynamics of knowledge diversity and economic growth. Southern Economic Journal, $77(4), 856-884$.

Bhawe, N., Zahra, S. A., Chao, C., \& Bruton. (2019). Protectionist policies and diversity of entrepreneurial types. Small Business Economics: Special issue on Diversity, Innovation, Entrepreneurship - Regional, Urban, National and International Perspectives, forthcoming.

Bishop, P. (2019). Knowledge diversity and entrepreneurship following an economic crisis: an empirical study of regional resilience in Great Britain. Entrepreneurship \& Regional Development, 31(5-6), 496-515.

Boschma, R., \& Iammarino, S. (2009). Related variety, trade linkages, and regional growth in Italy. Economic Geography, 85(3), 289-311.

Boschma, R., Eriksson, R., \& Lindgren, U. (2009). How does labour mobility affect the performance of plants? The importance of relatedness and geographical proximity. Journal of Economic Geography, 9(2), 169-190.

Brown, R., \& Mason, C. (2017). Looking inside the spiky bits: a critical review and conceptualisation of entrepreneurial ecosystems. Small Business Economics, 49(1), 11-30.

Capone, F., Lazzeretti, L., \& Innocenti, N. (2019), Innovation and diversity: the role of knowledge networks in the inventive capacity of cities. Small Business Economics: Special issue on Diversity, Innovation, Entrepreneurship - Regional, Urban, National and International Perspectives, forthcoming.

Chamberlain, E. H. (1933). The theory of monopolistic competition. Cambridge: Harvard University Press.

Cheng, S., \& Li, H. (2012). New firm formation facing cultural and racial diversity. Papers in Regional Science, 91(4), 759774.

Cohen, W. M., \& Levinthal, D. A. (1990). Absorptive capacity: a new perspective on learning and innovation. Administrative Science Quarterly, 35(1), 128-152.

Contractor, F. J., \& Lorange, P. (2002). The growth of alliances in the knowledge-based economy. International Business Review, 11(4), 485-502.

Davenport, S. (2005). Exploring the role of proximity in SME knowledge-acquisition. Research Policy, 34(5), 683-701.

Desrochers, P. (2001). Local diversity, human creativity, and technological innovation. Growth and Change, 32(3), 369-394.

Dixit, A. K., \& Stiglitz, J. E. (1977). Monopolistic competition and optimum product diversity. The American Economic Review, 67(3), 297-308.

Doran, J., Jordan, D., \& O'Leary, E. (2012). The effects of the frequency of spatially proximate and distant interaction on innovation by Irish SMEs. Entrepreneurship \& Regional Development, 24(7-8), 705-727.

Drejer, I., \& Vinding, A. L. (2007). Searching near and far: determinants of innovative firms' propensity to collaborate across geographical distance. Industry and Innovation, 14(3), 259-275.

Duranton, G., \& Puga, D. (2000). Diversity and specialisation in cities: why, where and when does it matter? Urban Studies, 37(3), 533-555.

Duranton, G., \& Puga, D. (2001). Nursery cities: urban diversity, process innovation, and the life cycle of products. American Economic Review, 91(5), 1454-1477.
Ellison, G., \& Glaeser, E. L. (1997). Geographic concentration in US manufacturing industries: a dartboard approach. Journal of Political Economy, 105(5), 889-927.

Ellison, G., \& Glaeser, E. L. (1999). The geographic concentration of industry: does natural advantage explain agglomeration? American Economic Review, 89(2), 311-316.

Eraydin, A., Tasan-Kok, T., \& Vranken, J. (2010). Diversity matters: Immigrant entrepreneurship and contribution of different forms of social integration in economic performance of cities. European Planning Studies, 18(4), 521-543.

European Commission. Directorate-General for Employment, \& Equal Opportunities. Unit D. (2005). The business case for diversity: Good practices in the workplace. Office for Official Publications of the European Communities http://ec.europa.eu/social/main.jsp?catId=780. .

Feldman, M. P. (1994). The geography of innovation. Boston: Kluwer.

Fitjar, R. D., \& Rodríguez-Pose, A. (2011). When local interaction does not suffice: sources of firm innovation in urban Norway. Environment and Planning A, 43(6), 1248-1267.

Florida, R. (2002). The rise of the creative class. New York: Basic Books.

Frenken, K., Van Oort, F., \& Verburg, T. (2007). Related variety, unrelated variety and regional economic growth. Regional Studies, 41(5), 685-697.

Fritsch, M. (2013). New business formation and regional development: a survey and assessment of the evidence. Foundations and Trends ${ }^{\circledR}$ in Entrepreneurship, 9(3), 249364.

Fritsch, M., \& Mueller, P. (2004). Effects of new business formation on regional development over time. Regional Studies, 38(8), 961-975.

Fritsch, M., Sorgner, A., \& Wyrwich, M. (2019). Types of institutions and well-being of self-employed and paid-employees in Europe. Small Business Economics: Special issue on Diversity, Innovation, Entrepreneurship - Regional, Urban, National and International Perspectives, forthcoming.

Fujita, M., \& Thisse, J.-F. (2002). Economics of agglomerationcities, Industrial location and regional growth. Cambridge: Cambridge University Press.

Fujita, M., \& Weber, S. (2003). Strategic immigration policies and welfare in heterogenous countries, Institute of Economics Research Paper. Kyoto: Kyoto University.

Grant, R. M., \& Baden-Fuller, C. (2004). A knowledge accessing theory of strategic alliances. Journal of Management Studies, 41(1), 61-84.

Greene, F. J., Mole, K., \& Storey, D. J. (2008). Three decades of enterprise culture: entrepreneurship, economic regeneration and public policy. New York: Palgrave Macmillan.

Hayter, C. S. (2013). Conceptualizing knowledge-based entrepreneurship networks: perspectives from the literature. Small Business Economics, 41(4), 899-911.

Henderson, J. V. (2005). Urbanization and growth. In Handbook of economic growth (Vol. 1, pp. 1543-1591). Amsterdam: Elsevier.

Hirsch, S. (1967). Location of industry and international competitiveness. Oxford: Oxford University Press.

Hong, L., \& Page, S. E. (2001). Problem solving by heterogeneous agents. Journal of Economic Theory, 97(1), 123-163.

Hong, L., \& Page, S. E. (2004). Groups of diverse problem solvers can outperform groups of high-ability problem solvers. 
Proceedings of the National Academy of Sciences, 101(46), $16385-16389$.

Huber, P., Landesmann, M., Robinson, C., Stehrer, R., Hierländer, R., Iara, A., ... \& Peng, F. (2010). Migration, skills and productivity. Verein "Wiener Inst. für Internat. Wirtschaftsvergleiche" (WIIW).

Huggins, R., \& Thompson, P. (2015). Entrepreneurship, innovation and regional growth: a network theory. Small Business Economics, 45(1), 103-128.

Huggins, R., \& Williams, N. (2011). Entrepreneurship and regional competitiveness: the role and progression of policy. Entrepreneurship \& Regional Development, 23(9-10), 907-932.

Hunt, J., \& Gauthier-Loiselle, M. (2010). How much does immigration boost innovation? American Economic Journal: Macroeconomics, 2(2), 31-56.

Jacobs, J. (1969). The economy of cities. London: Vintage.

Jaffe, A. B., Trajtenberg, M., \& Henderson, R. (1993). Geographic localization of knowledge spillovers as evidenced by patent citations. The Quarterly Journal of Economics, 108(3), 577598.

Johansson, B., \& Andersson, Å. E. (1998). A Schloss Laxenburg model of product cycle dynamics. In Knowledge and networks in a dynamic economy (pp. 181-219). Berlin, Heidelberg: Springer.

Johansson, J., Malmström, M., Parida, V., \& Wincent, J. (2019), How individual cognitions overshadow regulations and group norms: a study of government venture capital decisions. Small Business Economics: Special issue on Diversity, Innovation, Entrepreneurship - Regional, Urban, National and International Perspectives, forthcoming.

Karlsson, C. (2016). Clusters. In The new Palgrave dictionary of economics (pp. 1-16). London: Palgrave Macmillan.

Karlsson, C., \& Gråsjö, U. (2019). Knowledge flows, knowledge externalities and regional economic development. In M. M. Fischer \& P. Nijkamp (Eds.), Handbook of regional science (pp. 1-28). Berlin: Springer.

Kekezi, O., \& Klaesson, J. (2019). Agglomeration and innovation of knowledge intensive business services. Industry and Innovation, 1-24.

Kemeny, T. (2012). Cultural diversity, institutions, and urban economic performance. Environment and Planning A, 44(9), 2134-2152.

Kerr, W. R., \& Lincoln, W. F. (2010). The supply side of innovation: H-1B visa reforms and US ethnic invention. Journal of Labor Economics, 28(3), 473-508.

Krätke, S. (2010). Regional knowledge networks: a network analysis approach to the interlinking of knowledge resources. European Urban and Regional Studies, 17(1), 83-97.

Krugman, P. (1990). Rethinking international trade. Cambridge: The MIT Press.

Krugman, P. (1991). Geography and trade. Cambridge: MIT Press.

Labianca, G., \& Brass, D. J. (2006). Exploring the social ledger: negative relationships and negative asymmetry in social networks in organizations. Academy of Management Review, 31(3), 596-614.

Lavie, D. (2009). Capturing value from alliance portfolios. Organizational Dynamics, 1(38), 26-36.

Lazear, E. P. (1998). Personnel economics for managers. New York: Wiley.
Lazear, E. P. (1999). Globalisation and the market for team-mates. The Economic Journal, 109(454), 15-40.

Malecki, E. J. (2007). Cities and regions competing in the global economy: knowledge and local development policies. Environment and Planning C: Government and policy, 25(5), 638-654.

Malecki, E. J. (2010). Everywhere? The geography of knowledge. Journal of Regional Science, 50(1), 493-513.

Malecki, E. J. (2018). Entrepreneurship and entrepreneurial ecosystems. Geography Compass, 12(3), e12359.

Malizia, E. E., \& Feser, E. J. (1999). Understanding local economic development. New Brunswick: Center for Urban Policy Research Rutgers University.

Marshall, A. (1920). Principles of economics (8th ed.). London: Macmillan.

Mueller, P. (2006). Entrepreneurship in the region: Breeding ground for nascent entrepreneurs? Small Business Economics, 27(1), 41-58.

Naldi, L., Bau, M., Ahl, H., \& Markowska, M., (2019), Gender (in)equality within the household and business start-up among mothers. Small Business Economics: Special issue on Diversity, Innovation, Entrepreneurship - Regional, Urban, National and International Perspectives, forthcoming.

Nathan, M., \& Lee, N. (2013). Cultural diversity, innovation, and entrepreneurship: firm-level evidence from London. Economic Geography, 89(4), 367-394.

Neffke, F., Henning, M., \& Boschma, R. (2011). How do regions diversify over time? Industry relatedness and the development of new growth paths in regions. Economic Geography, 87(3), 237-265.

Nijkamp, P. (2003). Entrepreneurship in a modern network economy. Regional Studies, 37(4), 395-405.

Noteboom, B. (2000). Learning and innovation in organizations and economies. Oxford: Oxford University Press.

Nyström, K. (2019). Working for an entrepreneur: heaven or hell? Small Business Economics: Special issue on Diversity, Innovation, Entrepreneurship - Regional, Urban, National and International Perspectives, forthcoming.

Openshaw, S., \& Taylor, P. J. (1999). A million or so correlation coefficients: three experiments on the modifiable area unit problem. In N. Wrigley (Ed.), Statistical applications in the spatial sciences (pp. 127-144). London: Pion.

Ozgen, C., Nijkamp, P., \& Poot, J. (2012). Immigration and innovation in European regions. In P. Nijkamp, J. Poot, \& M. Sahin (Eds.), Migration impact assessment: new horizons (pp. 261-300). Northampton: Edward Elgar Publishing.

Page, S. (2007). The difference: how the power of diversity creates better groups. In Firms, Schools and Societies. Princeton: Princeton University Press.

Parrotta, P., Pozzoli, D., \& Pytliková, M. (2012) Does labor diversity affect firm productivity?. IZA Discussion Paper, No. 6973.

Parrotta, P., Pozzoli, D., \& Pytlikova, M. (2014). The nexus between labor diversity and firm's innovation. Journal of Population Economics, 27(2), 303-364.

Peri, G. (2007). Higher education, innovation and growth. In G. Brunello, P. Garibaldi, \& E. Wasmer (Eds.), Education and training in Europe (pp. 56-70). Oxford: Oxford University Press.

Porter, M. E. (1995). The competitive advantage of the inner city. Harvard Business Review, 73(3), 55-71. 
Pugh, R., Soetanto, D., Jack, S., \& Hamilton, E. (2019). Developing local entrepreneurial ecosystems through integrated learning initiatives: the Lancaster case. Small Business Economics: Special issue on Diversity, Innovation, Entrepreneurship - Regional, Urban, National and International Perspectives, forthcoming.

Qian, H. (2013). Diversity versus tolerance: the social drivers of innovation and entrepreneurship in US cities. Urban Studies, 50(13), 2718-2735.

Qian, H., \& Acs, Z. J. (2013). An absorptive capacity theory of knowledge spillover entrepreneurship. Small Business Economics, 40(2), 185-197.

Qian, H., Acs, Z. J., \& Stough, R. R. (2012). Regional systems of entrepreneurship: the nexus of human capital, knowledge and new firm formation. Journal of Economic Geography, 13(4), $559-587$.

Quigley, J. M. (1998). Urban diversity and economic growth. Journal of Economic Perspectives, 12(2), 127-138.

Rodríguez-Pose, A., \& Hardy, D. (2015). Cultural diversity and entrepreneurship in England and Wales. Environment and Planning A, 47(2), 392-411.

Rodríguez-Pose, A., \& von Berlepsch, V. (2018). Does population diversity matter for economic development in the very long term? Historic migration, diversity and county wealth in the US. European Journal of Population, 1-39.

Rosenthal, S. S., \& Strange, W. (2004). Evidence on the nature and sources of agglomeration economies. In V. Henderson \& J.-F. Thisse (Eds.), Handbook of urban and regional economics (Vol. 4, pp. 2119-2171). Amsterdam: Elsevier.

Sautet, F., \& Kirzner, I. (2006). The nature and role of entrepreneurship in Marekts: implications for policy. In Policy Primer ((4), Mercatus Policy Series). Washington, DC: George Mason University.

Schumpeter, J. A. (1934). The theory of economic development. Cambridge: Cambridge University Press.

Sobel, R. S., Dutta, N., \& Roy, S. (2010). Does cultural diversity increase the rate of entrepreneurship? The Review of Austrian Economics, 23(3), 269-286.

Sparber, C. (2007). Racial diversity and macroeconomic productivity across US states and cities. Hamilton: Colgate University.

Stam, E. (2007). Why butterflies don't leave: locational behavior of entrepreneurial firms. Economic Geography, 83(1), 27-50.

Stam, E. (2015). Entrepreneurial ecosystems and regional policy: a sympathetic critique. European Planning Studies, 23(9), 1759-1769.
Stam, E., \& van de Ven, A. (2019). Entrepreneurial ecosystem elements. Small Business Economics: Special issue on Diversity, Innovation, Entrepreneurship - Regional, Urban, National and International Perspectives, forthcoming.

Storper, M., \& Venables, A. J. (2004). Buzz: face-to-face contact and the urban economy. Journal of Economic Geography, 4(4), 351-370.

Stuart, T. E., \& Sorensen, O. (2005). Social networks and entrepreneurship. In S. Alvarez, R. Agarwal, \& O. Sorensen (Eds.), Handbook of entrepreneurship: disciplinary perspectives (pp. 211-228). Berlin: Springer, Berlin.

Südekum, J., Wolf K.,\& Blien U. (2009), Cultural Diversity and Local Labour Markets, University of Duisburg-Essen, Duisburg

Ter Wal, A. L., \& Boschma, R. (2011). Co-evolution of firms, industries and networks in space. Regional Studies, 45(7), 919-933.

Trax, M., Brunow, S., \& Suedekum, J. (2015). Cultural diversity and plant-level productivity. Regional Science and Urban Economics, 53, 85-96.

Tsvetkova, A. (2015). Innovation, entrepreneurship, and metropolitan economic performance: empirical test of recent theoretical propositions. Economic Development Quarterly, 29(4), 299-316.

Van Beers, C., \& Zand, F. (2014). R\&D cooperation, partner diversity, and innovation performance: an empirical analysis. Journal of Product Innovation Management, 31(2), 292312.

Van de Ven, H. (1993). The development of an infrastructure for entrepreneurship. Journal of Business Venturing, 8(3), 211230.

Vernon, R. (1966). International trade and international investment in the product cycle. Quarterly Journal of Economics, 80(2), 190-207.

Von Hippel, E. (1994). "Sticky information" and the locus of problem solving: implications for innovation. Management Science, 40(4), 429-439.

Winter, S. G. (1984). Schumpeterian competition in alternative technological regimes. Journal of Economic Behavior \& Organization, 5(3-4), 287-320.

Publisher's note Springer Nature remains neutral with regard to jurisdictional claims in published maps and institutional affiliations. 